\title{
Evolución tomográfica de la neumonía por SARS-CoV-2
}

\author{
Tomographic evolution of SARS-CoV-2 pneumonia
}

\section{Lorenzo Paz, (1) ${ }^{1}$ Glenda Ortíz.(1) ${ }^{2}$}

${ }^{1}$ Médico Residente, 4to Año, Postgrado de Radiología e Imágenes Médicas, Facultad de Ciencias Médicas (FCM), UNAH;

2Médico Especialista en Radiología, FCM UNAH; Departamento de Radiología, Instituto Hondureño de Seguridad Social; Tegucigalpa.

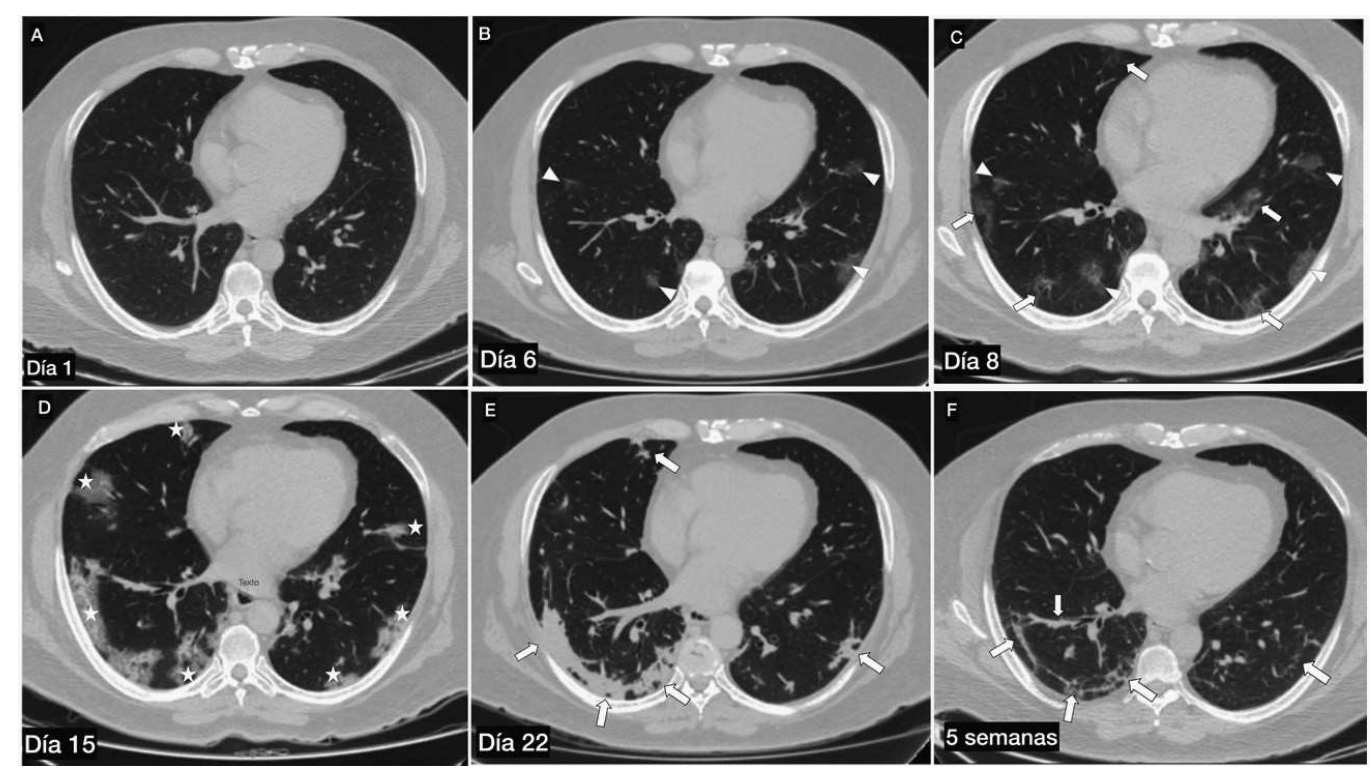

La COVID-19, producida por el virus SARS-CoV-2, causa un síndrome respiratorio agudo severo debido al desarrollo de neumonía intersticial. Se presentan imágenes características de neumonía por COVID-19 en paciente de 61 años de edad, sexo masculino, con diagnóstico confirmado por prueba PCR-RT, atendido en Tegucigalpa ambulatoriamente y posterior tratamiento intrahospitalario. Se realizaron tomografías de tórax en fase simple en diferentes fechas, con visualización de cortes axiales. Primer día de síntomas respiratorios, se observó parénquima pulmonar sin alteraciones (A). Sexto día de enfermedad, se identificaron escasas radioopacidades en vidrio deslustrado, parcheadas, periféricas, bilaterales ( $B$, punta de flechas; también marcado en $C$ ). Octavo día de enfermedad, se observó aumento de las radioopacidades en vidrio deslustrado ( $C$, flechas). Decimoquinto día de enfermedad, se evidenció patrón en empedrado bilateral, de predominio derecho confluentes ( $D$, asteriscos). Tres semanas de enfermedad, las áreas pulmonares afectadas progresaron a consolidaciones; sin embargo, se observó reducción de la afectación (E, flechas). Cinco semanas desde inicio de la enfermedad, se observaron bandas pleuroparenquimatosas residuales ( $F$, flechas). Estas características demuestran el curso típico de la enfermedad no complicada. Como se observa en las imágenes, la presentación y evolución clínica se puede valorar por tomografía computarizada, demostrando alta sensibilidad para el diagnóstico.

Recibido: 14-03-2021 Aceptado: 14-04-2021 Primera vez publicado en línea: 18-04-2021

Dirigir correspondencia a: Dra. Glenda Ortiz.

Detalles autores: 'lenda Ortiz, gortiz1us@yahoo.es;

2Lorenzo Paz, Ipazsantos2013@gmail.com.

DOI: https://doi.org/10.5377/rmh.v89i1.11579

(C) 2021 Autor(es): (c) (i)

Declaración de relaciones y actividades financieras y no financieras y conflictos de interés: ninguno. 